\title{
Pre-service ELT teachers' beliefs and perceptions on 21st century learning and innovation skills (4Cs)
}

\author{
Hasan Bedir ${ }^{\text {a } * \text { iD }}$ \\ APA Citation: \\ ${ }^{a}$ Cukurova University, Adana, 01330, Turkey
}

Bedir, H. (2019) Pre-service ELT teachers' beliefs and perceptions on the 21st century learning and innovation skills (4Cs). Journal of Language and Linguistic Studies, 15(1), 231-246.

Submission Date:12/02/2019

Acceptance Date:15/03/2019

\begin{abstract}
This study investigated ELT pre-service teachers' beliefs and perceptions on $21^{\text {st }}$ century learning and innovation skills with a special emphasis on critical, creative thinking, collaboration and communication skills (4Cs) in particular. Data were collected with a customized questionnaire including closed and open ended questions and semi-structured interviews. Results demonstrated that pre-service teachers mainly perceived $21^{\text {st }}$ century learning as the integration of technology into classrooms teaching. They were also moderately aware of and involved in $4 \mathrm{Cs}$ though they had high positive perceptions towards them. The words and phrases they used for the definition of critical, creative thinking, collaboration and communication were associated with the ones used in the educational context although $21^{\text {st }}$ century skills may have divergent or specialized meanings in different context. Pre-service teachers also held negative beliefs about emphasis of 4Cs in the national curriculum and assessment, but positive beliefs about professional development for $4 \mathrm{Cs}$.
\end{abstract}

(C) 2019 JLLS and the Authors - Published by JLLS.

Keywords: $21^{\text {st }}$ Century Learning; 4Cs; Pre-service teacher education;Pre-service teachers

\section{Introduction}

Education in the 21 st century gives much more emphasis on gaining necessary skills to learn and sustain learning not meet the needs of contemporary students since the curriculum was not originally structured to meet the societies' demands. Education must also aim at the development of a generation of people who will be able to acquire knowledge and skills to harness the power of digital technologies in widening their opportunities to gain the 4Cs (Trilling and Fadel, 2009). Scholars in the field of education have become aware of the need to modify or reconstruct the education systems to develop requisite knowledge, skills and dispositions necessary to satisfy the need of 21 st century learners.

Twenty first century education is briefly providing students with necessary skills which they can acquire and practice to become successful in globalized world. Partnership for 21st Century Learning (P21), (2007) and OECD (2018), taking into account the role of these skills in this age, have worked together for Education 2030 to translate the transformative competencies and other key concepts into a

\footnotetext{
${ }^{*}$ Corresponding author. Tel.: +90-322 3386084-Ext.2793-16
}

E-mail address: hbedir@cu.edu.tr 
set of specific constructs (e.g. creativity, critical thinking, responsibility, resilience, collaboration) so that teachers and school can better incorporate them into curricula (p.6). P21, (2009) has identified the four skills which are often used as 21st century learning and innovation skills and these skills are "increasingly being recognized as the skills that separate students who are prepared for increasingly complex life and work environments in the 21 st century, and those who are not" (p. 3). P21 also suggests that any teaching program aiming to prepare students for the future integrate creativity, critical thinking, communication, and collaboration skills. These are the skills most often cited when referred as the 4Cs of 21 st century learning and can be accomplished by reconstructing the curriculum aligned with the needs of individuals living in a global society.

\subsection{Literature Review}

Teacher education programmes are essential for the preparation of teachers to provide opportunities and challenges for the students to face the unknown future. A great number of countries have already reformed their education system and reconstructed their curriculum to change teachers' traditional pedagogic practices to those required for teaching and learning in the 21 st century. Teachers need to be experts in professional problem-solving and to be knowledgeable about technological pedagogical content knowledge since teaching to develop the 21 st century skills (Ball, Thames, and Phelps, 2008). However, many pre-service teacher preparation programmes focus only general skills, which results the ineffectiveness of bridging the gap between theory and practice in their real classroom teaching. can be difficult for them. Levine (2006) claimed that pre-service teacher education is the most important stage of having qualified teachers, indeed "the quality of tomorrow will be no better than the quality of our teacher force" (p. 11).

The main purpose of teacher education must, therefore, aim to enable pre-service teachers to develop a wide repertoire of educational techniques which enable them to build flexible and evolving strategies in response to the various teaching and learning scenarios they will meet in their classrooms. In addition, teacher training in the 21 st century aligned with innovated education policies must develop educational skills and enable teachers to integrate $21^{\text {st }}$ century skills to meet the demands of global economy. Freeman (2001) defines teacher education as "the sum of experiences and activities through which individuals learn to be language teachers" (p. 72). This process can be achieved through the courses in the curriculum (theory) and can be internalized by means of experience (practice). A good balance between theory and practice enable pre-service teachers to develop all the skills required to become professional teachers. In addition, Rotherham and Willingham (2009) suggest that schools should reconstruct their instructional methods and materials to teach and develop students' twenty-first-century skills.

Peters (2012) suggests that, "pre-service teachers need to develop the skills and attitudes that enable them to critically reflect on others' and their own practice" (p. 35). Teacher education institutions all over the world have been reconstructing their curriculum so that pre-service teachers can be qualified enough to effectively integrate the 4Cs into their instructional activities. Voogt et al. (2013) maintain that teachers be knowledgeable about the $4 \mathrm{Cs}$ in order to help students develop these skills. The authors also suggest that teachers should improve their pedagogical knowledge to align their subject teaching with the 4Cs. P21, (2015a) reports that the 4Cs which interrelated are 'super skills' for the 21 st century" (p. 1). pre-service teachers must gain these skills to integrate them into teaching and learning process, to improve the quality of teaching for 21 st century education. Thus, the role of ELT pre-service teachers for the implementation of the 4Cs is vital in transferring twenty-first century skills into school practice. The infusion of the 4Cs into ELT pre-service teacher education can enable them to emerge with the skills needed to be successful teachers of $21^{\text {st }}$ century. Table 1 presents a framework for the pedagogical meanings and implications of the 4Cs which was developed by referring to such well known frameworks 
as P21 (2007), contemporary literature and the opinions and research results of high-ranking professionals in the fields of education.

Table 1. Pedagogical Meanings and Implications of the 4Cs

\begin{tabular}{|c|c|}
\hline 4C Skills & Pedagogical Meanings and Implications \\
\hline Critical Thinking & $\begin{array}{l}\text { Critical thinking and reflection allow us to detect misconceptions and underlying } \\
\text { problems as well as see new opportunities in practice (Noonan, 2013, 177). } \\
\text { Critical thinking skills enable preservice teachers "to reflect on their practice in } \\
\text { meaningful ways, to consider the effect their teaching has on student learning, and } \\
\text { develop habits that will stay with them" (Ward \& McCotter, 2004, p. 244). } \\
\text { Pre-service teachers can involve in professional development activities; } \\
\text { Identify and ask significant questions that clarify various points of view and lead to } \\
\text { better solutions; } \\
\text { Frame, analyse and synthesize information in order to solve problems and answer } \\
\text { questions } \\
\text { Engage in learning experiences requiring in depth and complex thinking. Through } \\
\text { this process they analyse, infer, compare, reason, interpret, synthesize, and evaluate. } \\
\text { They also ask questions and approach the issues from different perspectives. }\end{array}$ \\
\hline Creative Thinking & $\begin{array}{l}\text { Creative thinking is developing the productive thought incorporating both creative } \\
\text { thinking of pre-service teachers. Creative thought can be imagining situations and } \\
\text { events, generating new characters or scenarios, producing tentative explanations or } \\
\text { solutions, and planning actions (Moseley et al., 2005, p. 313) } \\
\text { It is imperative for teacher education programs that they develop, model, and assess } \\
\text { what it means to be creative (Beghetto, 2007) } \\
\text { Pre-service teacher must demonstrate ability to work effectively and respectfully } \\
\text { with diverse teams; } \\
\text { Exercise flexibility and willingness to be helpful in making necessary } \\
\text { compromises to accomplish a common goal; } \\
\text { Plan instruction purposefully using a wide range of idea creation techniques } \\
\text { encourages students to apply creative thinking and problem solving skills. } \\
\text { When pre-service teachers examine and evaluate instructional methods from } \\
\text { different perspectives, they think in new directions, and synthesize information in } \\
\text { useful ways to demonstrate their creative thinking abilities. }\end{array}$ \\
\hline Collaboration & $\begin{array}{l}\text { Collaboration is commitment to work skilfully with others in groups. Collaborators } \\
\text { create effective groups by (1) establishing goals, (2) sharing ideas and workload, ( } 3 \text { ) } \\
\text { serving as facilitators and contributors, (4) sharing power and decision making, and } \\
\text { (5) engaging in productive conflict (Johnson \& Johnson, 2013, pp. 24-26). } \\
\text { Professional learning communities (PLCs) providing discussion is effectively used } \\
\text { to integrate collaboration and communication skills into pre- service teacher } \\
\text { education (Kagle, 2014). } \\
\text { Pre-service teachers also can work with their peers or in small groups to investigate } \\
\text { and collaborate to develop their content, pedagogical and technological knowledge. } \\
\text { They can also collaborate to discuss students' actions, find similarities and } \\
\text { differences between the students from different classes, to use graphic organizers } \\
\text { for drawing inferences or conclusions and etc about their teaching practices. }\end{array}$ \\
\hline Communication & $\begin{array}{l}\text { Communication is briefly to express themselves effectively, whether in productive } \\
\text { skills as spoken or written forms, or receptive skills as listening and reading. } \\
\text { Pre-service teachers must develop communication skills to exchange information, } \\
\text { feelings, and meaning through verbal and non-verbal messages; }\end{array}$ \\
\hline
\end{tabular}


Present their lessons using various channels of communication and multimedia formats.

Use tone of voice, facial expressions, gestures and body language effectively

They also learn how to use computers, the Internet and digital and mobile devices to make reading books and watching TV as an interactive communication activity

\subsection{The Turkish Context}

The current English language teacher education was reconstructed in accordance with the general objectives of Turkish National Education. It is a restructuring model of the previous program revising the pedagogic philosophy of both basic skills and values education with a basic focus on language use in an authentic communicative environment. The instructional structures were grounded an eclectic mix of instructional strategies so that learners can learn English as a medium of communication, rather than a school subject. The concepts related to 21 st century learning in the curriculum are "Critical thinking, Entrepreneurship, Problem solving, Communication, Collaboration, Decision making, Innovative thinking, Doing Research, ICT," (CoHE, 2017), yet there are no assessments policies or teacher training programs specifically targeted to these skills.

In addition, the current ELT curriculum provides the courses focusing more on basic knowledge and skills in separate subjects. ELT teacher candidates do not experience collaborative activities which enable them use curiosity and imagination, and then critical, creative thinking and collaboration and communication skills to generate new ideas and apply knowledge to new contexts. There were almost no policies for creativity development in education and no documents that guided both teaching and assessing the 4Cs. Evaluation of education quality is mainly based on sit down examinations. Bedir (2017) emphasized that the Turkish ELT teachers were not aware of 21st century learning and skills since ELT methodology was widely taught as a theoretical discipline with insufficient attention paid to a number of essential aspects such as critical and creative thinking, problem solving, ICT, etc. Teacher education curriculum must enable prospective teachers to develop clearly defined theoretical beliefs, which help them shape instructional strategies since they start teaching with beliefs about teaching. Thus, prospective teachers need better possibilities or professional development to be able to gain these skills. The vital step toward changing is that prospective teachers be provided authentic opportunities to practice new pedagogies along with their existing ones within situated contexts.

\subsection{The Current Study}

Teachers' beliefs, knowledge, skills and practice are affective in classroom teaching (Chan and Elliott, 2004), and the early established beliefs prospective teachers hold, prevail not only throughout the period of training but also persist during the early years of teaching. Cambridge Online Dictionary defines perception as "a belief or opinion, often held by many people and based on how things seem" and belief as "the feeling of being certain that something exists or is true." Kumaravadivelu (2012) discussed two types of beliefs and suggested core and peripheral beliefs which shape the teachers' professional development. According to the author, core belief is more effective in shaping teachers' instructional approaches while peripheral belief is not as effective as core belief since it paves way to the conflict between what teachers' claim they do and what they actually do in the classroom (p. 67).

There is a large body of literature to date on developing the 21 st-century skills through professional development for in-service about 21 st century learning and skills, the 4Cs which are by far the most popular. However, there is considerable deficiency in pre-service teacher education and teachers' beliefs, perception and knowledge about the 4Cs (Kurt, \& Önalan, 2018; Hagevik, Aydeniz, \& Rowell, 2012; Orhan-Goksun \& Askım Kurt, 2017); Jones \& Jones, 2013; Sural 2017). To address this emerging 
gap, the overarching goal of study aimed at investigating ELT pre-service teachers' beliefs and perceptions on the 21 st century learning. The research questions are thereby formulated as follows:

1. What are EFL pre-service teachers' general perceptions on $21^{\text {st }}$ century learning and skills?

2. What are EFL pre-service teachers' specific perceptions towards $21^{\text {st }}$ century learning and skills (4Cs) in the following aspects?

(a) the perceptions on critical thinking

(b) the perceptions of creative thinking

(c) the perceptions of collaboration

(d) the perceptions of communication.

3. What are the EFL pre-service teachers' specific beliefs toward the integration of the $4 \mathrm{Cs}$ in the following aspects?

(a) National curriculum and instruction

(b) assessment

(c) professional development.

\section{Method}

\subsection{Research Design}

An explanatory sequential mixed methods design was utilized in this study. It consisted of two phases where the quantitative phase was dominant which was supported with the qualitative data (Creswell and Clark, 2011). The quantitative data were collected from 124 pre-service teachers lasting two months. During the qualitative data collection phase, the researcher explored the pre-service teachers' perceptions on the $4 \mathrm{Cs}$ through focus group consisting of 12 participants.

\subsection{The participants and Setting}

The participants were pre-service English language teachers from Faculty of Education of a state university. A total of 124 pre-service teachers whose age ranged between 22-24 participated in the study, $27(21,77 \%)$ were male and $97(78,23 \%)$ were female. A group of 12 participants willing to develop both their skills and knowledge on 21 st century learning and innovation skills (4Cs) served as a focus group.

\subsection{Instrumentations and Data Collection}

Data were collected using a customized questionnaire including open-ended and closed ended questions developed by reviewing published literature. With 12 closed ended questions, the participants were expected to choose their preferences on a three-point Likert scale (Agree, No Idea and Disagree) and five open ended questions aimed to find out their perceptions and beliefs on the 4Cs. In addition, semi structured interviews were conducted with focus group for clarification of issues that were raised. The researchers developed a range of semi-structured questions the particular focus of which were given to open ended responses requiring clarification and "no idea" in the questionnaire; How important do you think the 4 Cs in education?

What do you mean with the integration of ICT?

What do you mean with thinking logically? 
What supports do teachers need to ingrate the 4Cs into language teaching?

What is the difference between working in cooperation and in collaboration?

Who is an effective communicator?

Borg (2006a) states that questionnaires and interviews are among the most common methods for eliciting teachers' beliefs and attitudes. The questionnaire data provided a descriptive overview of the pre-service teachers' perceptions and experiences of the 4Cs. The open ended questions were used to collect information about their thoughts, beliefs and feelings. The data collection tools were reviewed by two experts one of whom is working on curriculum development and the other is on teacher education development. According to their comments the unclear and obscure questions were revised and the complex statements were reworded to increase the reliability validity.

\subsection{Data analysis}

Both qualitative and quantitative analysis on research data were conducted as Berg (2009) suggested for analysing the pre-service ELT teacher education context in terms of the 4Cs. Open ended-questions aimed to investigate the pre-service teachers' perception on the 4Cs. Quantitative analysis was simply to administer descriptive statistical analysis using SPSS version 21.0. The interviews were videotaped and transcribed verbatim for qualitative analysis. Interview transcripts were first openly coded to identify relevant codes. Qualitative thematic analyses were employed for the interviews and responses to the open-ended questions. The responses were coded independently with key words and brief descriptions and they were shared and revised for consistent coding and categorizing (Gibbs, 2007).

The codes descriptions were used to tally frequency of the responses including broad patterns or noticeable responses. Deductive approach was utilized for qualitative analysis in that we determined some categories suggested by a theoretical perspective, literature review, and research questions or interview (Berg 2009). The responses were associated with previously set categories (Critical Thinking, Creative Thinking, Collaboration and Communication; the 4Cs). In data set, the responses to the open ended questions were tallied while searching for patterns that related to the guiding the purpose of the study (Creswell and Clark, 2011). Finally, the number of tallies in each category was presented in frequency distribution figures. The frequencies show each indicator of the $4 \mathrm{Cs}$ which were obtained from qualitative data. There were other indicators, but as frequencies were not meaningful they were not taken into consideration.

\section{Results}

The results of statistical analysis were given in Table 2. The frequencies and percentages present the pre-service teachers perceptions $21^{\text {st }}$ century learning and skills. Figures of bar charts display the perceptions on the 4Cs. Table 3 shows the pre-service teachers' beliefs on the National curriculum and instruction, assessment and professional development.

\subsection{Pre-service teachers' perceptions on $21^{\text {st }}$ century learning}

The data collected with open ended questions and interviews coded and themes were identified. Once all data was organized, they were tallied to use statistical analysis and the percentages were considered for interpretation. 
Table 2. The perceptions on $21^{\text {st }}$ century learning and skills

\begin{tabular}{cccc}
\hline Perceptions & $\mathrm{f}$ & $\%$ \\
\hline Integration of technology & 65 & 52,4 \\
Student centred & 9 & 7,6 \\
Contemporary & 8 & 6,5 \\
Multiple intelligences & 6 & 4,8 \\
Problem Solving & 6 & 4,8 \\
The 4Cs & 3 & 2,4 \\
Project Based & 3 & 2,4 \\
\hline
\end{tabular}

As seen the in table, more than half of the pre-service teachers perceive $21^{\text {st }}$ century as integration of technology into instructional practice for learning and teaching. However, the interview data provided further data that pre-service teachers who were regularly using technologies such as e-mail, text messages, and social networking websites for social interactions, perceive technology integration as using "smart board, internet and computer" in teaching and learning process. The qualitative data also revealed that they were using Power Point to visualize their presentations during their micro teaching experiences.

\subsection{Pre-service teachers' perceptions on the $4 C s$}

Teacher candidates' definitions of 21 st century learning and innovation skills demonstrated some overarching patterns, revealing pre-service teachers' fragmented perceptions of the 4Cs.

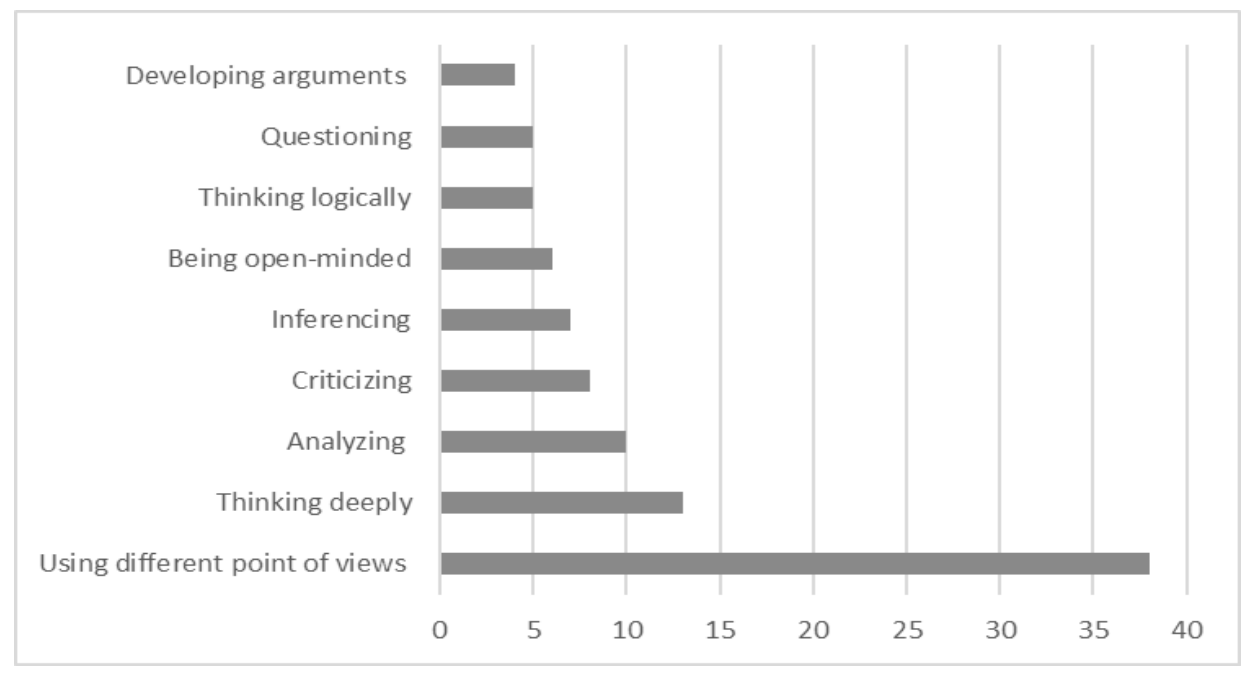

Figure 1. Perceptions on Critical Thinking

Figure 1 indicates that the highest range of frequency is "using different point of views" (38) and the lowest one is "developing arguments" which suggest that many of the pre-service teachers perceive critical thinking as looking into matters from different perspectives. They defined CT as a process that involves deeper thinking and analysing information. The data supported with interview also revealed that being critical, open-minded and asking questions are the dispositions of a critical thinking. The common point on that "Critical thinking enables teachers to be deeper thinker, critical and being openminded."

Five of the topics indicated by the pre-service teachers were logical thinking and four were developing arguments. These topics are resulted from the responses which were also associated with 
other topics. Many of the responses related to these topics were as "I think we should discuss the new methods, and develop new ideas on them and let our students develop arguments from a new point of view. "I believe critical thinking is to using a new point of view to defend my argument"

The further "I feel that critical thinking plays an important role in the learning process. If students are able to think critically, they will be able to perform better in class. A lot of students fail to perform well in their courses because they lack the understanding of how to apply the theories that they have learnt. The lack of application skills, I believe, it comes from the fact that they do not think critically."

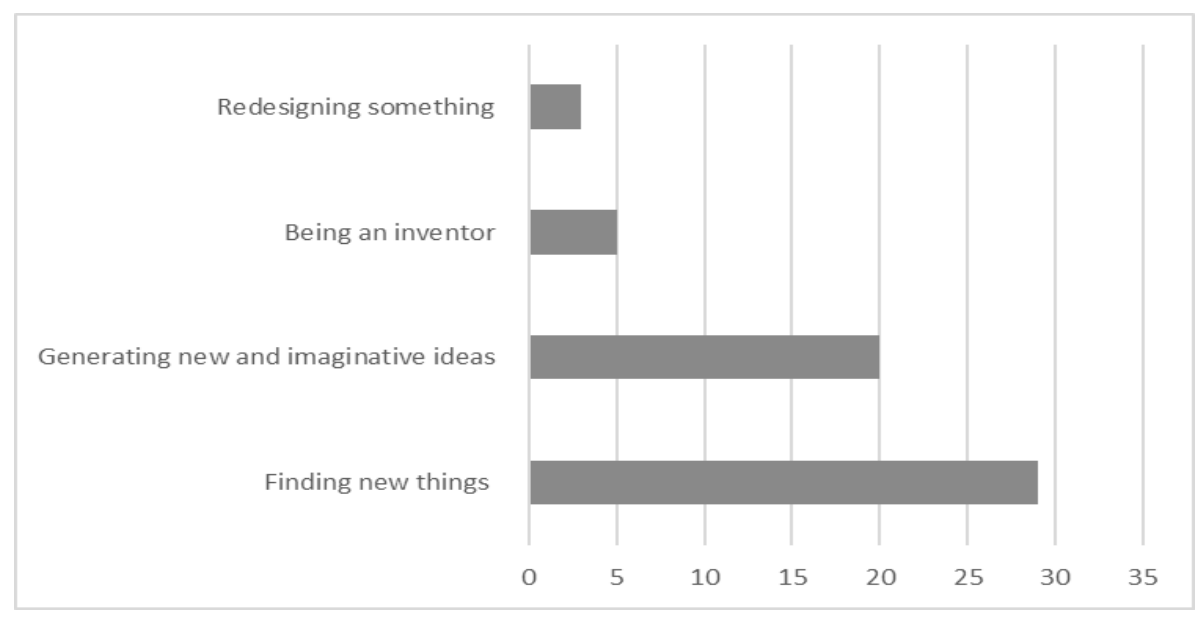

Figure 2. Perceptions on Creative Thinking

Pre-service teachers appeared not to have a comprehensive understanding of creativity and how to integrate it into teaching. They also did not highlight the classroom implementation of creativity for language teaching since they were not provided with the adequate knowledge supported by policies and curriculum. They tended to apply some creative tools that they felt familiar with and which were convenient to use. The majority of the pre-service teachers agreed that creativity in education is important, and they mentioned creativity from the similar aspects avoiding the negative side though they struggled to define creative thinking in specific terms. Majority of the words and phrases were associated with the production of new ideas and new things: finding new things (29), generating new and imaginative ideas (20), being an inventor (5) and redesigning something (3). It is obvious that preservice teachers seemed to be appreciating creative products more than creative processes. They were also holding misconceptions for creativity as they considered new as creativity.

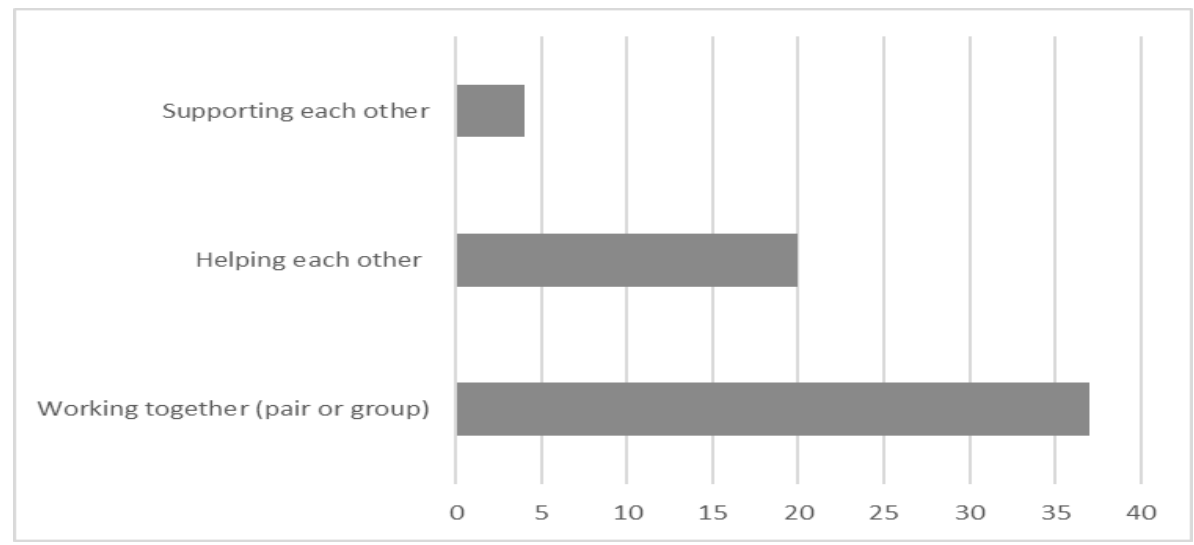

Figure 3. Perception on Collaboration 
As shown in Figure 3, the majority of the respondents perceived that collaboration is working together either pair or group work (37). The rest of the responses seem to be associated with becoming together to achieve a goal. However, interview data revealed that the pre-service teachers' perception of collaboration did not involve working together on the same task rather than division of the task. The majority of the pre-service teachers talked out "I like to work with my friend since I feel more confident. We share the roles and tasks and we work on our responsibility" They also talked about "with group work, we discuss with each other and when we work in groups we do not have fear." However, interview data revealed that their team related utterances were associated more with cooperation than collaboration though the distinction between the two was not necessarily clear-cut.

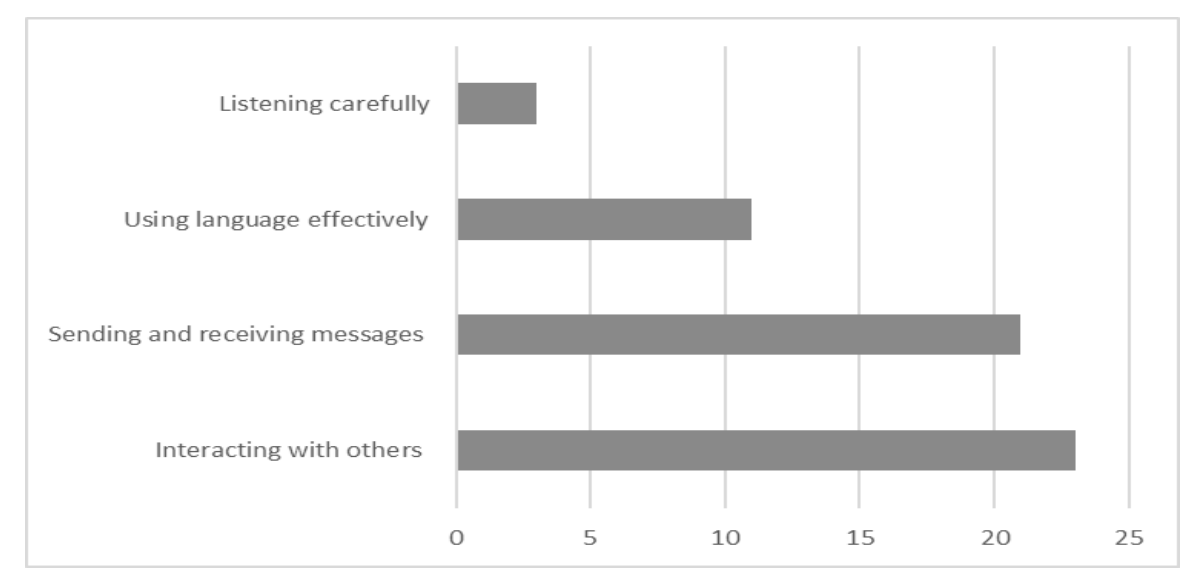

Figure 4. Perceptions on Communication

Figure 4 indicates that pre-service teachers are aware of many of the communication skills. However, they mostly indicated "interacting with others" and sending and "receiving messages." The common views on communication obtained in the interview were

"I have already taken a course in the first year called effective communication skills. In this course we learnt many things about communication and I know it is important for a teacher, but I am not sure I will be able to communicate well with my students"

\subsection{Pre-service Teachers' Beliefs on the 4 Cs in the Curriculum}

Teacher candidates' beliefs consisted of three domains: knowledge of National curriculum and instruction, knowledge of assessment and knowledge of professional development. Responses to each statement were scored on a 3-point Likert scale (from agree, to no idea) in terms of pre-service teachers' perceptions about the $4 \mathrm{Cs}$ and the curriculum.

Table 3. The beliefs on the $4 \mathrm{Cs}$ in the Curriculum

\begin{tabular}{|c|c|c|c|c|c|c|}
\hline \multirow[t]{2}{*}{ Statements } & \multicolumn{2}{|c|}{ Agree } & \multicolumn{2}{|c|}{ Disagree } & \multicolumn{2}{|c|}{ No Idea } \\
\hline & $\mathrm{f}$ & $\%$ & $\mathrm{f}$ & $\%$ & $f$ & $\%$ \\
\hline $\begin{array}{l}\text { 1. Ministry of National Education has } \\
\text { established } 21 \text { st Century skills the } 4 \text { Cs as } \\
\text { learning standards for all students across all } \\
\text { levels. }\end{array}$ & 38 & 30.64 & 52 & 69.35 & 34 & 27.41 \\
\hline $\begin{array}{l}\text { 2. The new curriculum is revised all to align } \\
\text { with the } 21 \text { st Century skills }\end{array}$ & 16 & 12.90 & 26 & 20.96 & 82 & 66.13 \\
\hline
\end{tabular}




\begin{tabular}{lcccccc}
$\begin{array}{l}\text { 3. Ministry of National Education has provided } \\
\text { teachers with access to digital content and } \\
\text { resources that are aligned to the 4Cs }\end{array}$ & 68 & 54.83 & 32 & 25.80 & 24 & 19.35 \\
$\begin{array}{l}\text { 4. Teaching and especially assessing the 4Cs } \\
\text { are important in 21st century. }\end{array}$ & 76 & 61.29 & 24 & 19.35 & 24 & 19.35 \\
$\begin{array}{l}\text { 5. The assessment of students' the 4Cs is } \\
\text { accomplished largely through teachers' use of } \\
\text { performance assessments (e.g., rubrics and } \\
\text { observations) within the classroom }\end{array}$ & 74 & 59.67 & 18 & 14.51 & 26 & 20.96 \\
$\begin{array}{l}\text { 6. I can use assessment tools for the students } \\
\text { attainment of the 4Cs }\end{array}$ & 14 & 11.29 & 94 & 75.80 & 16 & 12.90 \\
$\begin{array}{l}\text { 7. I need professional development to build } \\
\text { teaching for 21st century skills }\end{array}$ & 98 & 79.04 & 8 & 6.45 & 18 & 14.51 \\
$\begin{array}{l}\text { 8. Specific courses and/or professional } \\
\text { development is required for the 4Cs. }\end{array}$ & 101 & 81.45 & 7 & 5.64 & 16 & 12.90 \\
\hline
\end{tabular}

The quantitative results showed that a substantial number of pre-service teachers $(69,35 \%)$ disagreed on the statement "Ministry of National Education has established 21st Century skills (4Cs) as learning standards for all students across all levels" and more than half of them $(66,13 \%)$ did not have any idea about "The new curriculum is revised all to align with the 21 st Century skills." However, pre-service teachers with a relatively high percentage $(54,83 \%)$ agreed that "Ministry of National Education has provided teachers with access to digital content and resources that are aligned to 4Cs." This is assumed to have resulted from their observations of the classes equipped with multimedia.

The responses to the statement related to the assessment that measure $21^{\text {st }}$ century skills indicated that more than half of the pre-service teachers $(61,29 \%)$ believed the teaching and especially assessing the $4 \mathrm{Cs}$ are important in 21 st century. They also implied that summative assessment procedures can rarely measure the 4 Cs skills responding to the statement "The assessment of students' 21 st Century learning and innovation skills is accomplished largely through teachers' use of performance assessments (e.g., rubrics and observations) within the classroom" (59,67\% agree). However, they did not seem be ready enough to use tools appropriate for the 4Cs. "I can use assessment tools for the students' attainment of the 4 Cs $(75,80 \%$ disagree $)$.

According to needs aspect, pre-service teachers, with high agreement, rated the necessity of professional development in attempt to develop instructional strategies $(79,04 \%)$ and specific courses to increase their knowledge related to 21 st century learning skills $(81,45 \%)$. In the interviews, they indicated that "mastery of academic content and pedagogical knowledge could not enable them to equip students with such skills as critical thinking, problem solving, communication, collaboration and creativity."

\section{Discussion}

This study sought to examine pre-service ELT teachers' existent knowledge with $21^{\text {st }}$ century learning and innovation skills. Furthermore, the study examined their beliefs on the status of the 4Cs in the National Curriculum, assessment of the $4 \mathrm{Cs}$ and professional development.

ELT pre-service teachers perceived 21 st century learning and skills as the integration of technology into teaching and learning which requires teacher to improve their technological knowledge as well as pedagogical and content knowledge. Ministry of National Education weighed in on the importance of including technology within the curriculum to meet the needs of 21 st century learners. In ELT 
curriculum, the course Educational Technologies and Material Development is tailored to equip student teachers with adequate technology literacy and classroom applications. However, equipping the classrooms with technology does not necessarily mean that teacher can use them effectively. Sutton (2011) suggests that "preservice teacher's technology training experience should remain useful and relevant once they are placed in their own classroom" (p. 39). Willis and Tucker (2001) maintain that "teacher education programs do not prepare new teachers to be the change agents for the public school environment....Just teaching them how to use computers is not enough....Pre-service students need to experience alternative teaching and learning models and strategies as part of their own education. (p.4).

The results also provided a rather positive view of ELT pre-service teachers' for $21^{\text {st }}$ century learning and the $4 \mathrm{Cs}$ although they were not holding similar ones for the implementation of the $4 \mathrm{Cs}$. Considering the terms used for the $4 \mathrm{Cs}$, we can interpret that pre-service teachers' understanding related to $21^{\text {st }}$ century learning and innovation skills is at moderate level though they were not ready to implement the 4Cs in their teaching practice. This is consistent with the argumentation of Bedir (2017) in that "ELT teachers were not aware of 21 st century learning and skills" due to insufficient requirements from the curriculum and a strict culture of test-based assessment. The interview results revealed that the preservice teachers had an interest in the 4Cs and they had a desire to incorporate the teaching of these skills into the curriculum. Thus, they need a curriculum supported with profession development activities to improve their understanding on the 4Cs. The more pre-service teachers understand $21^{\text {st }}$ century skills the more they can develop their instructional strategies since when teachers advance their understanding they can become more confident to make decisions and apply teaching practice (Carlgren, 2013).

The results of critical thinking (CT) perceptions revealed that ELT pre-service teachers were perceiving $\mathrm{CT}$ as specific sets of skills rather than using multiple skills at one time. They also perceived CT as the key skills of the 4Cs and a skill which must be taught in order to help students perform better in class. These results support the findings reported in related literature in that students must be equipped with CT to become good thinkers and better learners (Black, 2005; Duron et al., 2006; Halpern, 2014). The perceptions on creativity, on the other hand, were deemed to be consistent with the previous studies in that the widely accepted perceptions are originality (new things) and usefulness (Runco and Johnson, 2002). In addition, beliefs on creativity can pave way to the development of creative instructional strategies when it is accepted one of the fundamentals of learning and teaching (Andiliou \& Murphy, 2010). Thus, it is not enough to understand creativity, and its importance does not necessarily lead to teaching for creativity since there is no explicit information about teaching and assessing the creativity in the Turkish National Curriculum (Ananiadou and Claro, 2009).

The results also indicated that ELT pre-service teachers were having high teamwork and collaboration-related perceptions since they used the terms as "working together, helping each other and supporting each other." These are consistent with the collaboration dimensions suggested by Handsley (2011) as "the skills of teamwork, working in groups, and working cooperatively with others which are essentials to achieve collaborative problem-solving tasks." The ELT pre-service teachers' perceptions about communication seem to be closely associated with what Trilling and Fadel (2009) suggested for good communicators. The authors stated that $21^{\text {st }}$ century communicator must "articulate thoughts and ideas effectively using oral, written and nonverbal communication skills, listen effectively to decipher meaning, including knowledge, values, attitudes and intentions, use communication to inform, instruct, motivate and persuade" (p.55). In addition, P21 (2014) maintains that "communication skills have always been valued in the workplace and in public life, but in the 21st century, these skills have been transformed and are even more important today" (p. 13).

Furthermore, ELT pre-service teachers were holding the idea that National Education Curriculum do not go beyond providing content knowledge and prepare teachers to integrate the $4 \mathrm{Cs}$ into subject 
teaching. In addition, they did not believe that National Education Curriculum have already aligned instruction standards with those that embody 21 st learning. Therefore, it is extremely important that they develop such professional abilities as to implement the $4 \mathrm{Cs}$ in their content area teaching. DarlingHammond, (2006) claim that preservice teachers should be guided to apply their content, pedagogical and technological knowledge in various educational contexts. The current century teachers do not aim to meet the needs of the 20 century learners, yet they must be "extremely well-educated and highly professional facilitator (s) of learning" (Slabbert, 2006, p. 5) to be able to gain and practice 21 st century knowledge and skills.

\section{Conclusions and Recommendations}

The purpose of this study was to unveil ELT preservice teachers' beliefs and perceptions on $21^{\text {st }}$ century education and skills, namely the 4Cs. Findings of both quantitative and qualitative data indicated that a great number of pre-service teachers perceive $21^{\text {st }}$ century learning and skills as the integration of technology into classroom teaching. The perceptions of substantial number of them related to how far current curriculum supports 21 st century learning and innovation skills and on the knowledge of how to assess them were also at low level. However, they believed that there should be professional development events since stand-alone regular instructional courses in the curriculum did not result in the integration of 21 st century skills?

In addition, almost all of the ELT pre-service teachers noted that many courses offered in the teacher preparation program touched on some overlapping themes such as metacognition, learning to learn, lifelong learning, professional development, critical and creative thinking. They also stated these that the activities carried out in the courses fairly helped the learning outcomes and the objectives of $21^{\text {st }}$ century pre-service teacher education, and there were no explicit assessment methods. Moreover, they indicated that they had never attended a course that focused on systematic approach to promoting professional development for the integration of the 4Cs.They further indicated that the courses in the curriculum did not equip them with meaningful context on the application educational technologies to integrate into teaching and learning. That is, ELT pre-service teachers were having high regards for their professionalism and high role standards and expectations of themselves for the $21^{\text {st }}$ century education.

Through an analysis of the current curriculum and the findings from quantitative and qualitative data, we raised the following suggestions; The recently reconstructed curriculum of teacher education institutions in Turkey endeavoured to promote teacher professional development and innovative teaching performance by providing various professional development courses, hence ELT pre-service teachers' professional development and innovative teaching activities are deemed as the core elements of integrating the 4Cs into curriculum. Adamson and Darling-Hammond (2010) suggest that the curriculum frameworks pave way to teacher training, professional development, and classroom practice. However, the $4 \mathrm{Cs}$ must be well defined and be deliberately inserted into specific courses since the courses in the curriculum of preservice teacher education can only teach general skills. Dede (2007) claims "guided inquiry, collaborative learning, mentoring, and apprenticeships to be more effective pedagogical strategies" (p. 17).

Although the research questions of this study refer specifically to the perceptions and beliefs of preservice teachers on the 4Cs in the context of English Language teaching, finding publications solely focusing on this topic proved a challenge, as, unfortunately, a very small number of study focus on the 4Cs in pre-service teacher education context. This poses the question of whether their perceptions and beliefs might change when they were imposed to a professional development module for the awareness and integration of the $4 \mathrm{Cs}$. This raises an interesting research gap to investigate in the future. As 
teachers' perceptions and beliefs change through training inevitably affecting the corresponding educational needs, structures, practice and goals, it would be interesting, as well as theoretically and practically valuable how the concept of the $4 \mathrm{Cs}$ is approached differently. Thus, we finally suggest that follow-up action research studies with the ELT preservice teachers in this study who will be teaching at different levels would help them to increase their knowledge on the 4Cs and integrate them into their instruction. This follow-up study could also examine the extent to which teachers and their students are meeting current expectations for 21 st century learning.

\section{Acknowledgement}

The author gratefully acknowledges financial support for this study by Çukurova University, Scientific Research Project Funding through SBT-2018-10181 project number.

\section{References}

Ananiadou, K., \& Claro, M. (2009). 21st century skills and competences for new millennium Learners in OECD countries. OECD Education Working Papers, No. 41, Paris, France: OECD Publishing.

Andiliou, A., \& Murphy, K. P. (2010). Examining variations among researchers' and teachers' conceptualizations of creativity: A review and synthesis of contemporary research. Educational Research Review, 5, 201-219.

Beghetto, R. A. (2007). Does creativity have a place in classroom discussions? Prospective teachers' response preferences. Thinking Skills and Creativity, 2, 1-9. doi:10.1016/j. tsc.2006.09.002.

Ball, D. L., Thames, M. H., \& Phelps, G. (2008). Content knowledge for teaching: What Makes It Special? Journal of Teacher Education, 59, p. 389.

Bedir, H. (2017). English language teachers' beliefs on 21 st century learning and innovation skills. Paper presented at Cukurova International ELT Teachers Conference (CUELT $\left.3^{\text {rd }}\right)$. Adana, Turkey.

Berg, B. L. (2009). Qualitative research methods for the social science. California State University: Pearson Publications.

Black, S. (2005). Teaching students to think critically. The Education Digest, 70(6), 42-47.

Borg, S. (ed.) (2006a). Classroom research in ELT in Oman. Ministry of Education, Sultanate of Oman.

Carlgren. T. (2013). Communication, critical thinking, and problem solving: A Suggested course for all high school students in the 21 st century. Interchange, 44, 63-81.

Chan, K., \& Elliott, R. G. (2004). Relational analysis of personal epistemology and conceptions about teaching and learning. Teaching and Teacher Education, 20, 817-831. 
Creswell, J. W., \& Plano Clark, V. L. (2011). Designing and conducting mixed methods research ( $2^{\text {nd }}$ ed.). Thousand Oaks, CA: Sage.

CoHE (2017). The English Language Teaching undergraduate program. In The New Undergraduate Teaching Programs Retrieved from http://www.yok.gov.tr/web/guest/icerik//journal_content/56_INSTANCE_rEHF8BIsfYRx/10279/41807946 on December 10, 2018

Darling-Hammond, L. (2010). The flat world of education: How America's commitment to equity will determine our future. New York, NY: Teachers College Press.

Darling-Hammond, L. (2006). Constructing 21st-century teacher education. Journal of Teacher Education, 57, 300-314. doi:10.1177/0022487105285962.

Dede, C. (2007). Transforming education for the 21 st Century: New pedagogies that help all students attain sophisticated learning outcomes. Harvard University: Commissioned by the NCSU Friday Institute.

Duron, R., Limbach, B., \& Waugh, W. (2006). Critical thinking framework for any discipline. International Journal of Teaching and Learning in Higher Education, 17(2), 160-166.

Duckworth, A. (2016). Grit: The power of passion and perseverance. New York, NY: Simon and Schuster.

Freeman, D. (2001). Second language teacher education. In R. Carter \& D. Nunan (Eds.). The Cambridge guide to teaching English to speakers of other languages (pp. 72-79). Cambridge: Cambridge University Press.

Gibbs, G.R. (2007) Thematic Coding and Categorizing, Analyzing Qualitative Data. SAGE Publications Ltd., London.

Hagevik, R., Aydeniz, M., \& Rowell, C. G. (2012). Using action research in middle level teacher education to evaluate and deepen reflective practice. Teaching and TeachingEducation, 28, 675684. doi:10.1016/j.tate.2012.02.006

Handsley, E. (2011). Good practice guide: Collaboration skills-threshold learning outcome 5Promoting excellence in Higher Education. Surry Hills, NSW: Australian Learning \& Teaching Council.

Halpern, D. F. (2014). Thought and knowledge: an introduction to critical thinking (5th ed.).New York, NY: Psychology Press.

Johnson, D. W., \& Johnson, F. P. (2013). Joining together: Group theory and group skills (11th ed). Boston: Allyn and Bacon.

Kagle, M. (2014). Professional learning communities for pre-service teachers. National Teacher Education Journal, 7(2), 21-25

Kumaravadivelu, B. (2012). Language teacher education for a Global Society. New York: Routlege.

Kurt, G., \& Önalan, O. (2018). Turkish Pre-service EFL Teachers' Perceptions of Creativity. International Online Journal of Education and Teaching (IOJET), 5(3). 636-647. http://iojet.org/index.php/IOJET/article/view/444/258

Levine, A. (2006). Educating School Teachers. Retrieved from http:www.edschools.org/pdf/Educating_Teachers_Report.pdf. on September, 16,2018. 
Moseley, D., Baumfield, V., Elliott, J., Gregson, M., Higgins, S., Miller, J., et al. (2005). Frameworks for thinking. Cambridge: Cambridge University Press., pp. 119 et seq

Noonan, S. (2013). How real teachers learn to engage all learners. Latham, MD: Rowman \& Littlefield Education.

OECD (2018). The future of education and skills: Education 2030. Retrieved from https://www.oecd.org/education/2030/E2030\%20Position\%20Paper\%20(05.04.2018).pdf on December 20, 2018

Orhan-Goksun, D., \& Askım-Kurt, A. (2017). The relationship between pre-service teachers' use of 21st century learner skills and use of 21st century teacher skills. Education and Science, 42(190), 107-130. doi:10.15390/EB.2017.7089.

P21, (2015a). Our Mission. Washington, DC: The Partnership for 21st Century Skills. Retrieved from http://www.p21.org/about-us/our-mission on December 12, 2018

P21, (2014). Learning for the 21st Century: A Report and MILE Guide for 21st Century Skills. Partnership for 21st Century Skills. Retrieved from https://files.eric.ed.gov/fulltext/ED480035.pdf

P21, (2009). P21 Framework Definitions. Partnership for 21st Century Skills (P 21). Retrieved from https://files.eric.ed.gov/fulltext/ED519462.pdf on December 21, 2018.

P21, (2007). P21's Framework for 21st Century Learning. Retrieved from http://www.p21.org/ourwork/p21-framework on December 12, 2018.

Peters, J. H. (2012). Are they ready? Final year pre-service teachers' learning about managingstudent behavior. The Australian Journal of Teacher Education, 37(9), 18-42. https://doi.org/10.14221/ajte.2012v37n9.2.

Rotherham, A.J., \& Willingham, D. (2009). Twenty-first-century skills: The challenges ahead. Educational Leadership, 67(1), p. 16-21.

Runco, M. A., \& Johnson, D. J. (2002). Parents' and teachers' implicit theories of children's creativity: A cross-cultural perspective. Creativity Research Journal, 14(3/4), 427-438.

Slabbert, J. A. (2006). Radically innovative: PGCE lecturer information package: University of Pretoria, Faculty of Education.

Sutton, S.R. (2011). The Preservice technology training experiences of novice teachers. Journal of Digital Learning in technology Education, 28(1), 39-47.

Trilling, B., \& Fadel, C. (2009). 21 st century skills: Learning for life in our times. San Francisco, CA: John Wiley \& Sons.

Sural, I. (2017). 21st century skills level of teacher candidates. European Journal of Education Studies, 3(8), 530-538.

Voogt, J., Erstad, O., Dede, C., \& Mishra, P. (2013). Challenges to learning and schooling inthe digital networked world of the twenty-first century. Journal of Computer Assisted Learning, 29, 403-413.

Ward, J. R., \& McCotter, S. S. (2004). Reflection as a visible outcome for preservice teachers. Teaching and Teacher Education, 20, 243-257. doi:10.1016/j.tate.2004.02.004

Willis, E. M., \& Tucker, G. R. (2001). Using constructionism to teach constructivism: Modeling hands-on technology integration in a preservice teacher technology course. Journal of Computing in Teacher Education, 17(2), 4-7. 


\section{İngilizce Öğretmen Adaylarının 21. Yüzyıl Öğrenme ve Yenilikçilik Becerilerine İlişkin İnanç ve Algıları (4C)}

\section{$\ddot{O} \mathbf{z}$}

Bu çalışma, İngilizce öğretmen adaylarının 21. yüzyıl öğrenme ve yenilikçilik becerileri ile ilgili inanç ve algılarını özellikle eleştirel ve yaratıcı düşünme, işbirliği ve iletişim becerilerine (4Cs) özel bir vurgu yaparak incelemiştir. Veriler, kapalı ve açık uçlu sorular içeren özelleştirilmiş bir anket ve yarı yapılandırılmış görüşmeler ile toplanmıştır. Sonuçlar öğretmen adaylarının 21. yüzyıl öğrenimini çoğunlukla teknolojinin derslere uyarlanması olarak algıladıklarını göstermiştir. Ayrıca, eleştirel ve yaratıcı düşünme, işbirliği yapma ve iletişim becerileri konusunda orta derecede farkındalık ancak bu becerilere karşı oldukça pozitif algı göstermişlerdir. Eleştirel ve yaratıcı düşünme, işbirliği ve iletişimin tanımlanmasında kullandıkları sözcükler ve ifadeler 21. yüzyıl becerilerinin farklı bağlamlarda farklı veya özel anlamlar ile kullanılmalarına rağmen eğitim bağlamında kullanılanlarla ilişkiliydiler. Öğretmen adayları ayrıca, bu becerilerin ulusal müfredat da yerleri ve değerlendirme araçları hakkında olumsuz, ancak bu konuda mesleki gelişim ile ilgili olumlu inançlara sahip oldukları ortaya çıkmıştır.

Anahtar sözcükler: 21. Yüzyıl Öğrenme; 4C; Öğretmen adayı eğitimi; Öğretmen adayları

\section{AUTHOR BIODATA}

Assoc. Prof. Dr. Hasan Bedir is a graduate of ELT Department Faculty of Education, Cukurova University. He completed his MA and Ph.D at the same university. He is studying on Teacher Education and 21st Century Skills. He is specifically teaching Educational Research Methods, Teaching English to Young Learners and Material Evaluation and Development at undergraduate level, Critical Thinking in ELT at MA and Current Trends in Teacher Education at Ph.D. 